\section{Exploratory spatial analysis of diabetes mortality and its relationship with the socioeconomic conditions of Colombian municipalities}

\author{
Análisis espacial exploratorio de la mortalidad \\ por diabetes y la relación con condiciones \\ socioeconómicas en los municipios colombianos
}

\author{
Análise espacial exploratória da mortalidade \\ por diabetes e a relação com condições \\ socioeconômicas nos municípios colombianos
}

\author{
Karen Valeria Montoya-Betancur 1 \\ Beatriz Caicedo-Velásquez 2 \\ Luz Stella Álvarez-Castaño 1
}

doi: 10.1590/0102-311X00101219

\begin{abstract}
Type 2 diabetes mellitus prevalence has increased worldwide, especially in low- and middle-income countries. This study aimed to evaluate in the Colombian context whether the geographic variations of mortality due to type 2 diabetes mellitus are random or statistically significant and to measure the effect of the socioeconomic conditions of municipalities on these variations. An ecological study of trends for regions and subregions was undertaken considering two periods (2003-2009 and 2010-2016). The study population consisted of adults of 20 to 79 years old residing in each of Colombia's municipalities during the period 2003-2016. Smoothed and standardized mortality rates were obtained by fitting a hierarchical Bayesian model, which considers the spatial structure of the data. Four socioeconomic variables related to municipal deprivation and development were included into the model to obtain their relative risk $(R R)$ and $95 \%$ credible intervals. Mortality due to type 2 diabetes mellitus decrease between 2003 and 2016 in Colombia, both nationally and regionally. In addition, there was a clear positive association between mortality due to diabetes mellitus and the level of municipal development; the wealthiest and most developed municipalities had higher mortality risks.
\end{abstract}

Type 2 Diabetes Mellitus; Nutritional Status; Spatial Analysis; Social Determinants of Health; Mortality

\author{
Correspondence \\ K. V. Montoya-Betancur \\ Crra. 58, n. 42-02 int 240, Copacabana, Antioquia \\ 051040, Colombia. \\ karenmontoya0228@gmail.com \\ ${ }^{1}$ Escuela de Nutrición y Dietética, Universidad de Antioquia, \\ Medellin, Colombia. \\ 2 Facultad Nacional de Salud Pública, Universidad de \\ Antioquia, Medellín, Colombia.
}




\section{Introduction}

Type 2 diabetes mellitus is a chronic, noncommunicable disease characterized by insulin resistance caused by hyperglycemia due to inadequate insulin production and inability of tissues to respond to the effects of insulin. Among the main complications are cardiovascular disease, blindness, kidney failure and lower limb amputation. It has also been associated with increased cancer rates, physical and cognitive disability, tuberculosis, and depression 1,2.

425 million people worldwide between the ages of 20 and 79 suffered from diabetes in 2017, of which $90 \%$ were type 2 , with an increasing prevalence. It is estimated that by 2045 this may reach $9.9 \%$. In South America, the current prevalence is $9.6 \%$ and an increase of $65 \%$ is expected by 20452 .

In 2010, the prevalence of type 2 diabetes mellitus in Colombia of patients between 20 and 79 years ranged from $4 \%$ to $8 \%$; it was one of the main five causes of death. Following the global and regional trends, Colombia has experienced a marked increase in the prevalence of mortality due to this disease. Likewise, according to the Ministry of Health and Social Care Colombia shows marked differences between its departments, where Antioquia, Bogotá and Valle del Cauca featured the highest prevalence in 2014, while Vaupés, Vichada, Putumayo, Guainia and Chocó had the lowest prevalence 3.

Studies conducted worldwide have found heterogeneous trends among countries and differences in relation to the most affected social groups. A study conducted in Spain analyzing the mortality trend from type 2 diabetes mellitus between 1998-2013 found a general decreasing trend, with higher rates in women 4. A study that compared type 2 diabetes mellitus mortality in Mexico, Argentina, Chile, and Colombia found that unlike the other countries, the prevalence of the disease in Colombia tended to decrease, with higher rates in women 5. Another study conducted in Argentina showed an increasing mortality, which was higher in men and in those individuals without health coverage 6 .

Type 2 diabetes mellitus is strongly related to overweight or obesity and abdominal obesity. Likewise, the literature shows that the risk of developing type 2 diabetes mellitus increases with age and sedentary lifestyles. Higher prevalence was found in women and certain racial and ethnic groups, such as the black and native populations 2. Regarding internal differences, geographical variations have been associated not only with the risk conditions of the inhabitants of the different departments but also with socioeconomic differences and the development of these territories ${ }^{3}$. According to the International Diabetes Federation ${ }^{2}$, the increase in prevalence is greater in countries with medium or low incomes, where the nutritional transition to an increasingly processed diet is occurring rapidly. In turn, other international health institutes also highlight the impact of socioeconomic and environmental factors on the development of type 2 diabetes mellitus, indicating that globalization, urbanization and access to education and health services contribute to the creation or modification of environments, which has a direct impact on the behavior of individuals in the communities, altering their eating patterns, physical activity and social interactions $1,7,8,9$.

Much of the literature supports the positive relationship between the prevalence of type 2 diabetes mellitus and the poor socioeconomic conditions of areas affected. However, there are also inconsistencies; for example, Borrell 10 carried out a study with data from 11 Spanish cities, and at the census tract level, and in most cities, zones of greater socioeconomic disadvantage had the highest risk of female mortality due to diabetes. Likewise, Connolly et al. 11 showed that the prevalence of type 2 diabetes mellitus was greater in areas of greater economic deprivation when compared to wealthier areas. Another ecological study in nine English cities found that the incidence of type 2 diabetes mellitus was higher in cities with poorer socioeconomic conditions 12. A study in Bangladesh showed an inverse relationship, with the risk of mortality due to diabetes being higher in urban areas and areas of greater wealth, even after controlling for other risk factors 13 . Likewise, a study in China found that the prevalence of diabetes was twice as high in areas of high urbanization compared to less urbanized areas 14,15.

In Colombia, numerous studies on the epidemiology of diabetes have been conducted 3,8,16,17; however, the spatial context of the disease has not been explored in terms of its variation and clustering patterns (clusters) at small geographical scales, such as municipalities, nor has it been analyzed for its relationship with the unequal socioeconomic conditions of the municipalities. For this type of analysis, spatial epidemiology and Geographic Information Systems (GIS) are crucial, as they are increasingly used in epidemiological research in applications such as mortality atlases, both worldwide and at 
the municipal level (Universidad de Antioquia. Atlas de la salud de Colombia. http://www.desigualda dessalud.org, accessed on 14/Jan/2019) 2,18,19.

This work is part of a broader project that studies the patterns and relationships between mortality by different causes and the socioeconomic conditions of the Colombian municipalities to identify possible socio-geographical inequities. This study aimed to use GIS and spatial analysis to determine the spatial patterns of mortality by type 2 diabetes mellitus at the municipal level in Colombia during the period 2003-2016. The objective was to evaluate whether the geographic variations of mortality due to type 2 diabetes mellitus are random or statistically significant and to measure the effect of the socioeconomic conditions of the municipalities on these variations.

\section{Materials and methods}

\section{Design, study population and unit of analysis}

An ecological trend design was used between the years 2003-2016. The study population consisted of men and women between 20 and 79 years of age who lived in Colombian municipalities during the study period.

The geographical units of analysis were Colombian regions and municipalities. According to the 2005 Political-Administrative Division of Colombia (DIVIPOLA. Departamento Administrativo Nacional de Estadística. Geoportal. https://geoportal.dane.gov.co/, accessed on Apr/2018), Colombia was divided into six regions and 1,119 municipalities. For the present analysis, a map was created at the municipal level to improve estimates. For this map, subdivisions or areas not municipalized were added to their respective capital city. Likewise, the four municipalities created after 2005 were regrouped into their municipalities of origin. Finally, the municipalities of San Andrés, Providencia and Santa Catalina were excluded due to the lack of contiguous or neighboring areas that allowed carrying out reliable municipal estimates of their mortality risks. Consequently, this study analyzed the data for 1,096 municipalities and six regions (Atlantic, Central, Bogotá, Eastern, Pacific, and Orinoquía and Amazonia).

\section{Information sources}

The population data and the number of deaths due to diabetes of people residing in Colombian municipalities during 2003-2016, detailed by age and sex, were obtained from the Colombian National Administrative Department of Statistics (DANE. Microdatos. http://microdatos.dane.gov.co, accessed on 30/ Jun/2017).

Socioeconomic indicators were also obtained from DANE, as well as from the United Nations Development Program (UNDP. Índice de desarrollo humano: 2015. http://hdr.undp.org/es/data, accessed on 14/Jan/2018) for Colombia, and from the National Planning Department (DNP) 20,21,22.

\section{Dependent variable}

The dependent variable was mortality caused by type 2 diabetes mellitus at the municipal level in individuals between 20 and 79 years of age; which included mortality due to primary causes of death, codified according to the 10th revision of the International Classification of Diseases from E110 to E119. This variable was estimated for two periods: 2003-2009 and 2010-2016.

\section{Independent variables: municipal socioeconomic conditions}

Four socioeconomic indicators were analyzed:

(i) Percentage of municipal population with unmet basic needs (UBN). This variable measures the proportion of the population that had at least one of the following characteristics in 2005: inadequate housing, housing with critical overcrowding, housing with inadequate services, housing with high economic dependence, and housing with school-age children not attending school 21. The municipalities 
were categorized into quintiles, with the lowest quintile comprising the wealthiest municipalities and the highest quintile, the poorest.

(ii) Human development index (HDI). This variable measures the degree of development achieved by each municipality for the year 2005 in three dimensions: health, education and income (UNDP. Índice de desarrollo humano: 2015. http://hdr.undp.org/es/data, accessed on 14/Jan/2018). The municipalities were categorized into quintiles, with the lowest quintile comprising municipalities with low human development and the highest quintile comprising municipalities with high human development.

(iii) Municipal economic importance. This score classifies municipalities in five categories according to their level of added value to their department. Added value is measured by the relative weight that represents the Gross Domestic Product (GDP) of each municipality within its department 23. Municipalities in category one have major importance and municipalities in category five have minor importance.

(iv) Multidimensional poverty index (MPI). This variable measures the percentage of people living in poverty in the following dimensions of quality of life: educational conditions of the household, childhood and youth conditions, health, work, access to public domiciliary services and housing conditions for the year 2005 24. Municipalities were categorized into quintiles, with the lowest quintile comprising the richest group of municipalities and the highest quintile comprising the poorest.

\section{Statistical analysis}

For the descriptive analysis of each period, mortality rates were estimated for men and women standardized by age for each of the six Colombian regions and for the categories of socioeconomic variables. For this, the direct method was used, taking as reference the Colombian population of each period. These rates were estimated using the Epidat statistical package (https://www.sergas.gal/Saude-publica/ EPIDAT).

At the municipal level, two risk indicators were estimated: the standardized mortality risk ratio (SMR) and the smoothed mortality risk ratio (sSMR) and the posterior probability (PrP) 25 . The first indicator was obtained through indirect standardization methods comparing the deaths observed in each period, municipality and gender with the deaths expected in the first period, municipality, and gender. The number of expected deaths was calculated from Colombia's age-specific mortality rates for the period 2003-2016 using ranges of five years. To facilitate its interpretation, the SMR was multiplied by 100 , where 100 was the risk of mortality in Colombia. Any value greater than 100 represented excess risk compared to Colombia, and values less than 100 represented lower risk.

The SMR were smoothed (sSMR) using the Bayesian hierarchical model proposed by Besag et al. 26 (Besag, York and Mollié model - BYM model). This model combines the mortality data of each municipality with the average of the neighboring municipalities. The BYM model was specified separately for the two periods and for men and women as 25 :

$$
\begin{gathered}
Y_{i} \text { Poisson }\left(\pi_{i}{ }^{\prime}\right. \\
\log \left(\pi_{i}\right)=\log \left(E_{i}\right)+\beta_{0}+v_{i}+u_{i}
\end{gathered}
$$

Where $Y_{i}$ is the observed number of deaths in each municipality with mean $i$. The expected number of deaths in each municipality $\left(E_{i}\right)$ is called the offset. $\pi_{i}$ represents the SMR and sSMR in the logarithmic scale, while the random effects $v_{i}$ and $u_{i}$ represent the non-spatial and spatial variability. A priori distributions of spatial effects were assigned through an intrinsic conditional autoregressive (ICAR) distribution with variance $\sigma_{\mathrm{u}}^{2}$. Regarding non-spatial effects, a normal distribution with zero mean and variance $\sigma_{\mathrm{v}}^{2}$ was udes. Initial values for the variance parameters $v_{i}$ and $u_{i}$ were assigned from a gamma distribution $(0.001,0.001) 27$. The result of the model is the respective posterior mean of the sSMR and their $95 \%$ credible interval.

$\operatorname{PrP}$ is an indicator that measures the probability of the sSMR being greater than 100 for each municipality, that is, the municipality's probability of having a significant excess of mortality compared to national data. According to other studies 25,28, $\operatorname{PrP}$ is considered significant above 0.8 (i.e., there is a greater than $80 \%$ probability that the sSMR is above 100). Likewise, municipalities whose PrP was less than $20 \%$ were considered to have a lower risk (i.e., there is a less than $20 \%$ probability that the sSMR is 
above 100). Both indicators were obtained using the INLA (Integrated Nested Laplace Approximation) method available in the INLA library of the statistical package R 2.15.3 (http://www.r-project.org) 29 .

To analyze the spatial pattern of municipal diabetes mortality for men and women, three types of analysis were carried out: (i) visualization of the spatial distribution of sSMR and PrP through thematic maps; (ii) calculation of descriptive non-spatial statistics showing the relationship between the socioeconomic conditions of the municipality and mortality; this was carried out via tables; and (iii) an exploratory spatial analysis of the sSMR that enabled the identification and evaluation of clusters of municipalities with high and/or low risk of mortality from diabetes mellitus. For this we used the global Moran statistic (I Moran) and the local statistic (Local Index of Spatial Autocorrelation - LISA) ${ }^{30}$. Both indicators are widely used in epidemiological research and have the advantage of producing results that are easy to visualize and understand. Through a statistical test, the global indicator measures the null hypothesis of whether the sSMR presents a spatial pattern with a tendency for clustering, dispersion or randomization ${ }^{31}$. Rejection of the null hypothesis suggests the presence of a special pattern or nonrandom spatial structure. In addition to this statistical test, the global indicator measures the degree of correlation of mortality among the municipalities analyzed, with values that vary between -1 and +1 , where positive values are evidence of clustering municipalities with similar SSMR, and negative values indicate that municipalities are different from each other in their mortality risks 32 . The local indicator LISA complements the global indicator, showing "where" the clusters of municipalities with similar or dissimilar values are located. This is accomplished through a map that groups the municipalities into four classes: high-high (municipalities with a high sSMR surrounded by municipalities with a high sSMR), low-low (municipalities with a low sSMR surrounded by those with a low sSMR), low-high (municipalities with a low sSMR surrounded by those with a high sSMR), and high-low (municipalities with a high sSMR surrounded by those with a low sSMR). Given the great variability in size, the estimation of both indicators required that the spatial contiguity of the municipalities be calculated with a first-order queen contiguity weight matrix 33 , considering neighboring municipalities as those that share a side or a vertex.

The analysis considered significance levels of $\mathrm{p}<0.05$. This exploratory spatial analysis was performed by using ArcGIS 10.5 software (http://www.esri.com/software/arcgis/index.html).

The article is concluded with the evaluation of the relationship between the risk of mortality due to diabetes mellitus and the socioeconomic conditions of the municipalities in the two periods, as well as its changes over time. For this, the BYM model was extended as an ecological regression model that separately included in level-2 the socioeconomic variables, the study period, and their interaction:

\section{$Y_{i}$ Poisson $\left(\pi_{i}^{\prime}\right.$, \\ $\log \left(\pi_{i}\right)=\log \left(E_{i}\right)+\beta_{0}+\beta_{1 j}$ Period $_{i j}+\sum \beta_{2}$ Socioeconomic $_{j}+\sum \beta_{3 i j}$ Period $_{i j} *$ Socioeconomic $_{j}+v_{i}+u_{i}$}

Where $\beta_{2}$ represents the effect of the category of the socioeconomic variable on diabetes mortality, being the reference categories the municipalities in better socioeconomic conditions (lower UBN, higher HDI, greater economic importance and lower multidimensional poverty). The interaction coefficient between socioeconomic variables and time is represented by $\beta_{3}$. A statistically significant interaction indicates that the risk of mortality associated with the socioeconomic variable varied in the study period.

These models were estimated using the INLA algorithms available in the INLA library of the statistical package R. 3.3.0 (http://www.r-project.org).

This research protocol was approved by the Ethics Committee from the Health Department of Antioquia University with the reference number 161 of March 9th, 2017. 


\section{Results}

Between 2003 and 2016, 1,597,005 deaths were reported in Colombia of individuals between 20 and 79 years of age, of which 18,055 were due to type 2 diabetes mellitus (1.13\%). During the study period, 947 municipalities reported at least one case of diabetes mortality in at least one year, and 13\% of the municipalities did not present any case of mortality in any year. In the first period (2003-2009), the median observed number of deaths due to diabetes mellitus in a given municipality was three, while in the second period (2010-2016), it was two. The trend of the mortality rate between the periods showed a decrease, changing from 6.94 cases per 100,000 inhabitants in 2003-2009 to 3.31 cases per 100,000 inhabitants in 2010-2016.

This decreasing trend was observed for women as well as for men, however women showed, throughout the entire period, a greater mortality risk compared to men. In the 2003-2009 period, the mortality rate for men was 6.03 cases per 100,000 male inhabitants (5.86-6.19), while for women there were 7.03 cases per 100,000 female inhabitants (6.85-7.19). For the period 2010-2016, the rate for men was 3.04 (2.93-3.15), while for women, this was 3.25 (3.13-3.35).

These observed reductions are partly due to the decrease in diabetes mortality in both women and men over 65 years.

Regarding regional results, for both periods the highest rates for men were in the Eastern region (composed of the departments of Santander, Boyacá, Cundinamarca and Meta). For women, the highest rates were in the Atlantic region (composed of Guajira, Cesar, Magdalena, Atlántico, San Andrés, Bolívar, Sucre and Córdoba) in the first period and in Orinoquía and Amazonia (departments of Arauca, Casanare, Guainía, Vichada, Amazonas, Putumayo, Guaviare, Vaupés) in the second period. In general, there was a decreasing tendency in the mortality rates of the regions, except for the Orinoquía and Amazonia, where there was an increase for both men and women, but this was not statistically significant (Table 1).

At the municipal level, there were also reductions in mortality (Figure 1). For the 2003-2009 period, $4 \%$ of the municipalities showed risks of male mortality that were significantly higher than those of Colombia (sSMR > 50\%), with these being mainly located in the Eastern and Pacific regions (formed by the departments of Valle del Cauca, Cauca, Nariño and Chocó). Municipalities that stand out in the Eastern region are Bucaramanga, Cúcuta, Floridablanca, Villavicencio, Cáqueza, Girardot and San Gil and in the Pacific region are Tuluá, Florida, Yumbo, Palmira, Bugalagrande and La Unión. For the period 2010-2016, less than 1\% of the municipalities showed this behavior, highlighting the municipalities of Villavicencio, Acacias, Cumaral and San Carlos de Guaroa, all belonging to the Eastern region.

Regarding female mortality, in the period 2003-2009, 9\% of the municipalities showed a risk level that was significantly higher than that of Colombia (sSMR > 50\%). These municipalities were located mainly in the Central, Atlantic and Eastern regions (consisting of Antioquia, Caldas, Risaralda, Quindío, Tolima, Huila and Caquetá), where the municipalities of Coveñas, Bosconia, Santiago de Tolú and Sincelejo stand out for the Atlantic region; Tebaida, Pacora, Neiva, Honda and Villavieja for the central region,

Table 1

Adjusted mortality rates for type 2 diabetes mellitus in the regions of Colombia, by sex and periods.

\begin{tabular}{lcccc}
\hline Region & \multicolumn{3}{c}{ Rate per 100,000 inhabitants (95\%Cl) } \\
& $\mathbf{2 0 0 3 - 2 0 0 9}$ & $\mathbf{2 0 1 0 - 2 0 1 6}$ & $\mathbf{2 0 0 3 - 2 0 0 9}$ & $\mathbf{2 0 1 0 - 2 0 1 6}$ \\
\hline Atlantic & $6.49(6.10-6.89)$ & $2.96(2.71-3.22)$ & $8.45(8.05-8.90)$ & $4.12(3.82-4.43)$ \\
Eastern & $7.37(6.94-7.81)$ & $4.95(4.61-5.28)$ & $8.37(7.92-8.80)$ & $4.76(4.43-5.09)$ \\
Bogotá & $6.91(6.45-7.40)$ & $2.76(2.48-3.04)$ & $4.69(4.32-5.04)$ & $2.00(1.81-2.25)$ \\
Central & $4.67(4.40-4.99)$ & $1.90(1.72-2.10)$ & $5.69(5.41-6.04)$ & $2.33(2.10-2.54)$ \\
Pacific & $5.84(5.45-6.24)$ & $3.01(2.75-3.28)$ & $6.25(5.88-6.62)$ & $3.22(2.93-3.49)$ \\
Orinoquía and Amazonia & $3.82(2.96-4.85)$ & $4.27(3.45-5.23)$ & $5.12(4.09-6.32)$ & $5.23(4.26-6.36)$ \\
\hline
\end{tabular}

95\%Cl: 95\% credible interval. 


\section{Figure 1}

Spatial distribution of the relative risk of mortality due to type 2 diabetes mellitus in men and women between 20 and 79 years of age and their respective a posteriori probability (PrP) of having a smoothed mortality risk ratio (SSMR) greater than that of Colombia, 2003-2016.

1a) Men (2003-2009) - sSMR

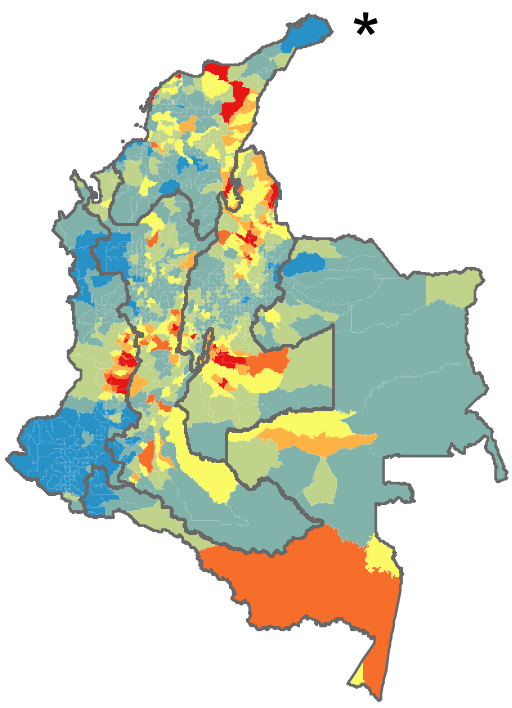

1c) Women (2003-2009) - SSMR

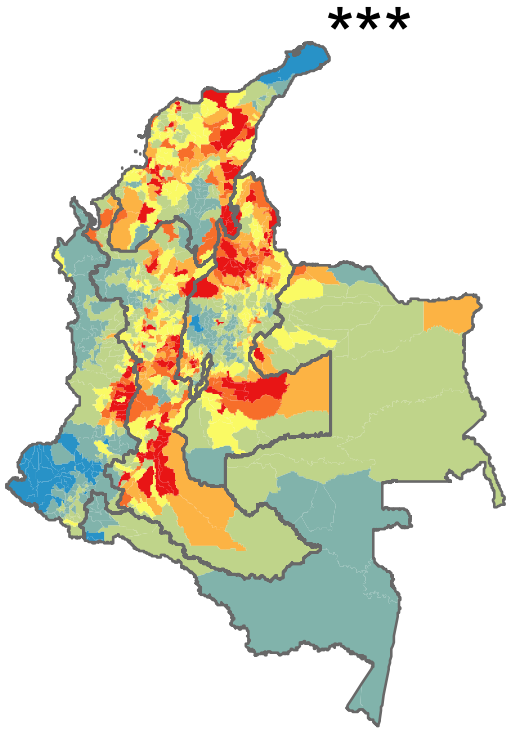

1b) Men (2010-2016) - sSMR

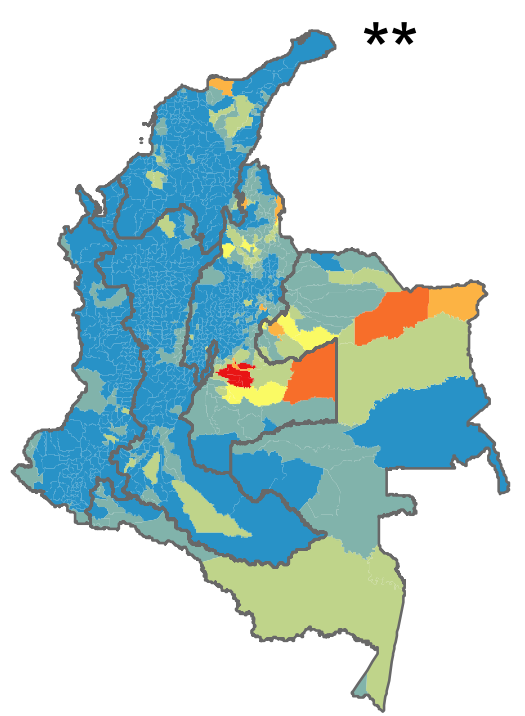

1d) Women (2010-2016) - SSMR

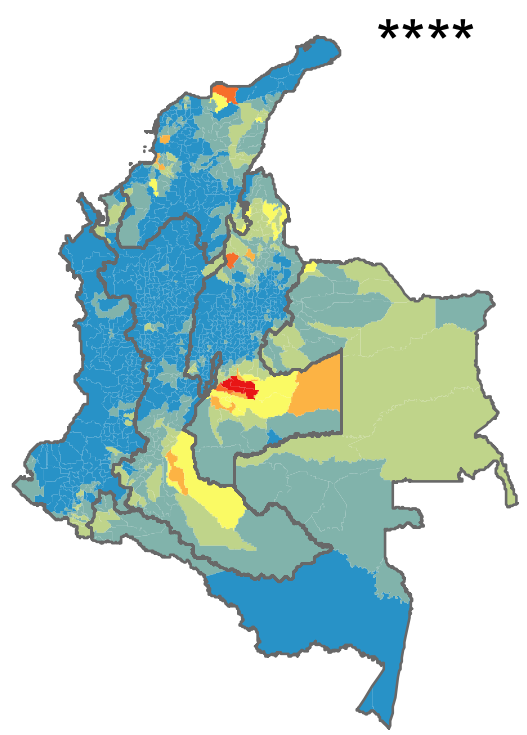

(continues)

and Bucaramanga, Cúcuta, Floridablanca, Villavicencio and Ocaña for the Eastern region. In the period 2010-2016, only three municipalities had a risk higher than that of Colombia: Villavicencio, San Carlos Guaroa and Acacias, all of which are in the Eastern region (Figure 1).

The results of the Moran index revealed positive and significant spatial autocorrelations $(\mathrm{p}<0.05)$, indicating the presence of significant groupings of municipalities with a high mortality risk due to diabetes. The I Moran for men in the first period was 0.63 and was 0.60 in second period. When applying 
1e) Men (2003-2009) - PrP

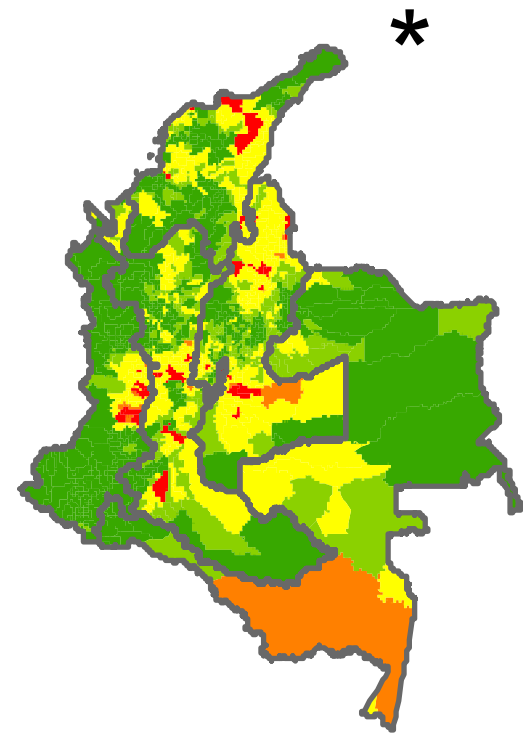

1g) Women (2003-2009) - PrP

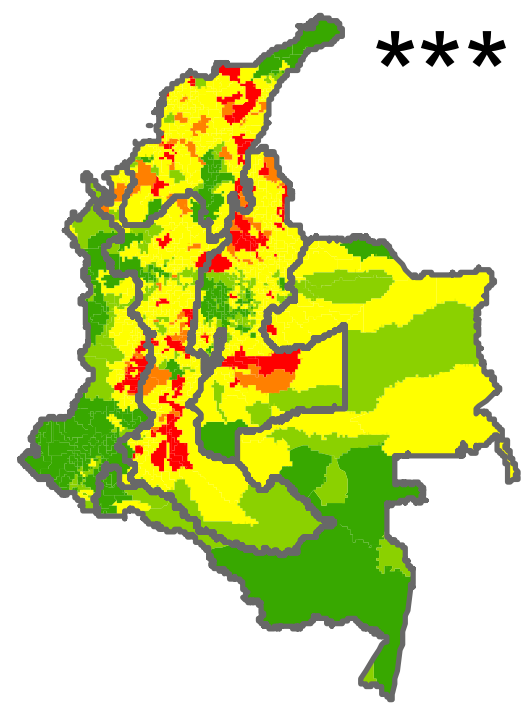

1f) Men (2010-2016) - PrP

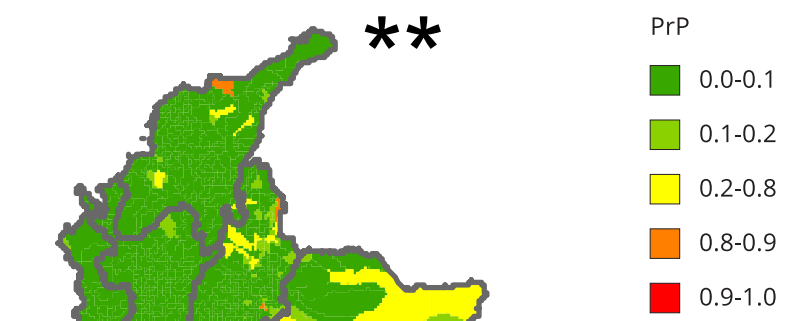

1h) Women (2010-2016) - PrP

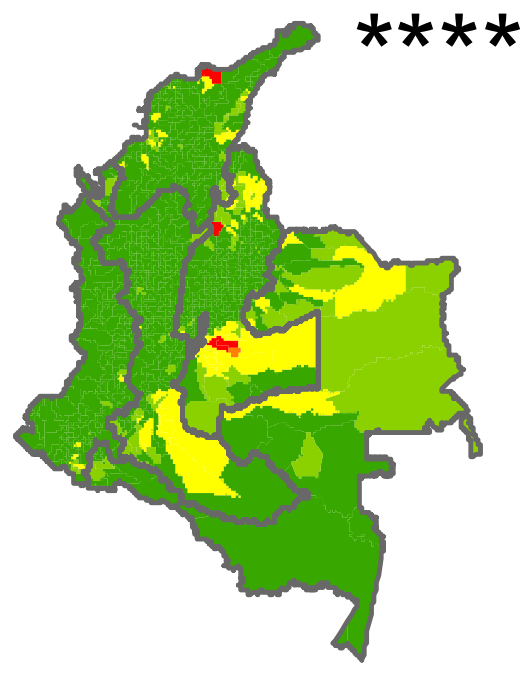

Note: the stars indicate the PrP corresponding to each relative risk map.

the LISA method (Figure 2), municipality clusters with high mortality risks were found in the first period in the Central, Eastern, Pacific and Atlantic regions that are located towards the center and north of the country, while in the second period, high rates were found in the Atlantic, Eastern, and Orinoquía and Amazonia regions in the east and south. Regarding women, the I Moran was 0.57 and 0.63 in the first and second periods, respectively, and both were statistically significant, with spatial clusters distributed in a way similar to that in men. For the first period, the clusters were found mainly in the Atlantic, Central and Eastern regions, in areas of the north and center of the country, while in the second period, there 


\section{Figure 2}

Results of the local Moran (Local Index of Spatial Autocorrelation - LISA) for standardized mortality risk ratio (SMR) due to type 2 diabetes mellitus in men and women between 20 and 79 years old, Colombia, 2003-2016.

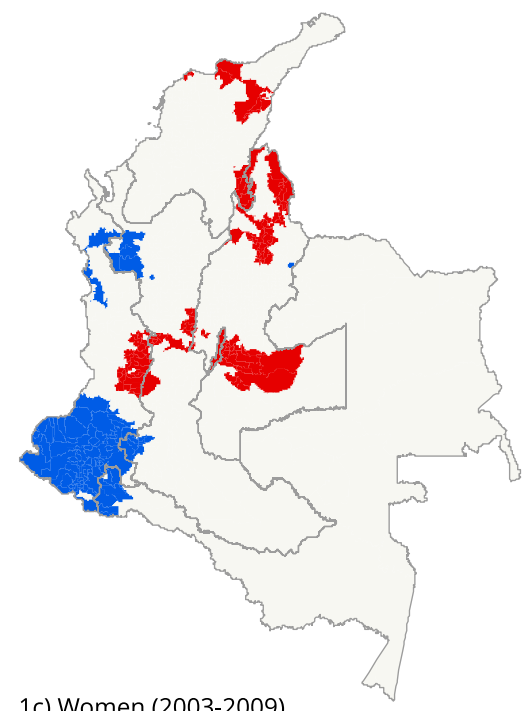

1c) Women (2003-2009)

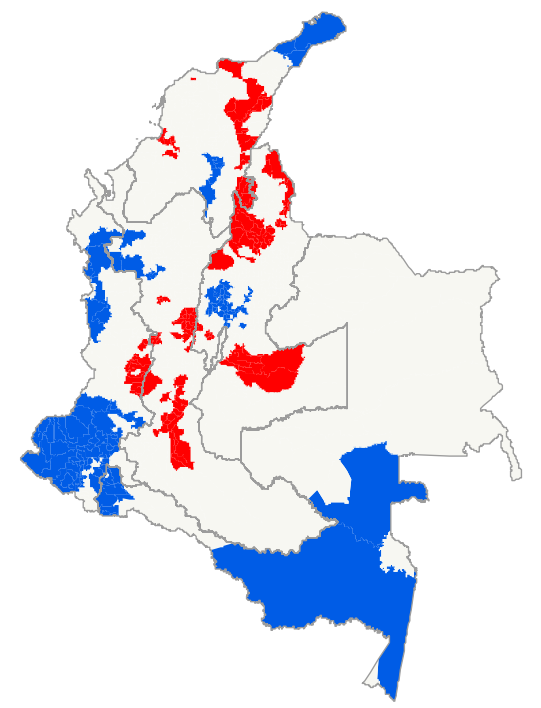

1b) Men (2010-2016)

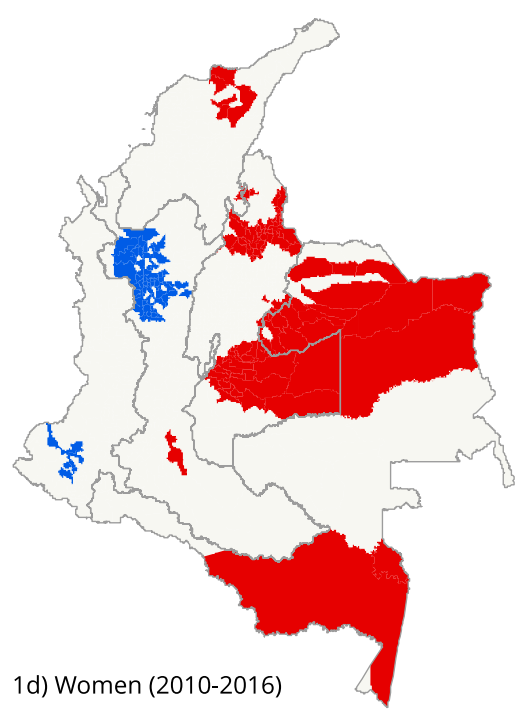
Not significan
High-high
Low-low
High-low
Low-high

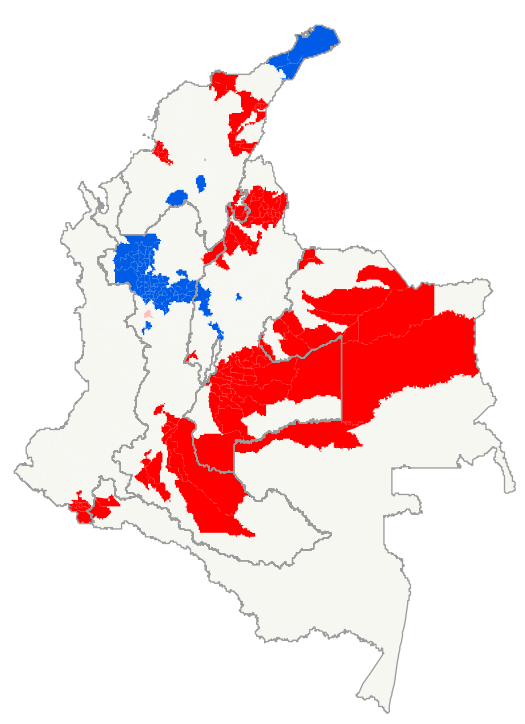

was a greater concentration in the Central, Eastern and Orinoquía and Amazonia regions, in the eastern and southern areas of the country (Figure 2).

Table 2 shows the mortality rates standardized by age according to the socioeconomic characteristics of the municipalities. For the two analyzed periods, we found a greater mortality risk due to type 2 diabetes mellitus in the richest, most developed and most economically important municipalities. According to the UBN indicator, the mortality risk due to diabetes mellitus is higher in the lower poverty quintiles; such difference tends to decrease in the second period for men. In turn, municipalities with greater 
human development and lower multidimensional poverty had a higher mortality risk due to diabetes; however, these differences decreased statistically significantly in the second period. Similarly, the municipalities with greater importance showed higher mortality risk (Table 2).

Corroborating these findings, Table 3 shows the results of the ecological regression between the mortality risk due to diabetes and the socioeconomic conditions of the municipalities. The mortality due to diabetes showed a negative social gradient, where wealthier municipalities and those with high levels of development and economic importance had a significantly higher mortality risk due to diabetes for individuals between 20 and 79 years of age.

Table 2

Type 2 diabetes mellitus mortality rate of men and women according to the socioeconomic characteristics of the municipalities. Colombia, 2003-2016.

\begin{tabular}{|c|c|c|c|c|}
\hline \multirow[t]{3}{*}{ Indicator } & \multicolumn{4}{|c|}{ Rate per 100,000 inhabitants $(95 \% \mathrm{CI})$} \\
\hline & \multicolumn{2}{|c|}{ Men } & \multicolumn{2}{|c|}{ Women } \\
\hline & 2003-2009 & $2010-2016$ & 2003-2009 & $2010-2016$ \\
\hline \multicolumn{5}{|l|}{$\begin{array}{l}\text { Percentage of municipal } \\
\text { population with UBN }\end{array}$} \\
\hline Lower poverty & $11.10(10.70-11.50)$ & $5.17(4.91-5.42)$ & $6.77(6.57-7.01)$ & $6.12(5.76-6.51)$ \\
\hline Quintile 2 & $11.80(10.90-12.60)$ & $5.73(5.16-6.33)$ & $8.54(7.99-9.10)$ & $8.45(7.39-9.64)$ \\
\hline Quintile 3 & $10.80(9.86-12.00)$ & $6.58(5.79-7.45)$ & $7.70(7.08-8.38)$ & $12.00(10.20-14.10)$ \\
\hline Quintile 4 & $10.50(9.10-12.20)$ & $3.83(3.33-4.38)$ & $6.24(5.71-6.84)$ & $7.03(6.03-8.16)$ \\
\hline Higher poverty & $4.72(4.11-5.42)$ & $3.07(2.59-3.59)$ & $5.09(4.58-5.63)$ & $4.36(3.69-5.14)$ \\
\hline \multicolumn{5}{|l|}{ HDI } \\
\hline Less development & $0.57(0.49-0.69)$ & $0.30(0.22-0.37)$ & $4.55(4.06-5.09)$ & $2.76(2.38-3.18)$ \\
\hline Quintile 2 & $7.08(6.28-7.89)$ & $3.12(2.65-3.60)$ & $6.68(6.14-7.30)$ & $3.68(3.29-4.13)$ \\
\hline Quintile 3 & $9.17(8.20-10.20)$ & $4.04(3.50-4.66)$ & $6.70(6.13-7.35)$ & $3.54(3.12-3.99)$ \\
\hline Quintile 4 & $11.80(10.90-12.90)$ & $4.86(4.33-5.44)$ & $8.89(8.31-9.54)$ & $4.17(3.78-4.57)$ \\
\hline More development & $84.80(82.10-87.60)$ & $33.40(31.90-34.90)$ & $6.89(6.68-7.10)$ & $2.95(2.83-3.10)$ \\
\hline \multicolumn{5}{|c|}{ Municipal economic importance } \\
\hline Major importance & $21.54(21.30-21.60)$ & $25.02(24.60-25.10)$ & $24.60(24.30-24.70)$ & $23.30(28.10-28.40)$ \\
\hline 2 & $6.09(5.80-6.30)$ & $7.23(6.90-7.50)$ & $6.48(6.20-6.70)$ & $7.68(7.40-7.90)$ \\
\hline 3 & $3.92(3.70-4.10)$ & $4.41(4.10-4.70)$ & $3.95(3.70-4.10)$ & $4.49(4.20-4.80)$ \\
\hline 4 & $5.13(4.90-5.30)$ & $5.67(5.40-5.90)$ & $4.92(4.70-5.10)$ & $5.47(5.20-5.70)$ \\
\hline Less importance & $4.57(4.30-4.80)$ & $4.94(4.60-4.30)$ & $4.24(4.10-4.40)$ & $4.59(4.40-4.70)$ \\
\hline \multicolumn{5}{|l|}{ MPI } \\
\hline Lower poverty & $7.17(6.95-7.40)$ & $3.35(3.20-3.50)$ & $7.10(6.89-7.30)$ & $3.07(2.93-3.24)$ \\
\hline Quintile 2 & $4.67(4.22-5.14)$ & $2.75(2.42-3.12)$ & $7.40(6.81-8.00)$ & $3.22(2.84-3.61)$ \\
\hline Quintile 3 & $4.56(4.12-5.04)$ & $2.38(2.04-2.73)$ & $7.17(6.59-7.81)$ & $3.81(3.40-4.24)$ \\
\hline Quintile 4 & $4.26(3.80-4.77)$ & $2.84(2.50-3.21)$ & $7.54(6.87-8.24)$ & $4.40(3.93-4.90)$ \\
\hline Higher poverty & $2.52(2.17-2.93)$ & $1.80(1.51-2.11)$ & $4.49(4.01-5.03)$ & $2.95(2.60-3.38)$ \\
\hline
\end{tabular}

95\% Cl: 95\% credible interval; HDI: human development index; MPI: multidimensional poverty index; UBN: unmet basic needs. 
Table 3

Relative risks (RR) of type 2 diabetes mellitus mortality for men and women according to the municipal socioeconomic conditions. Colombia, 2003-2016.

\begin{tabular}{|c|c|c|c|c|}
\hline \multirow[t]{3}{*}{ Indicator } & \multicolumn{2}{|c|}{ Men } & \multicolumn{2}{|c|}{ Women } \\
\hline & 2003-2009 & 2010-2016 & 2003-2009 & 2010-2016 \\
\hline & RR $(95 \% \mathrm{Cl})$ & RR $(95 \% \mathrm{Cl})$ & RR $(95 \% \mathrm{Cl})$ & RR $(95 \% \mathrm{Cl})$ \\
\hline \multirow{2}{*}{\multicolumn{5}{|c|}{$\begin{array}{l}\text { Percentage of municipal } \\
\text { population with UBN }\end{array}$}} \\
\hline & & & & \\
\hline Lower poverty & 1.00 & 1.00 & 1.00 & 1.00 \\
\hline Quintile 2 & $0.34(0.25-0.45)$ & $0.27(0.19-0.38)$ & $0.36(0.27-0.47)$ & $0.30(0.22-0.40)$ \\
\hline Quintile 3 & $0.20(0.14-0.27)$ & $0.17(0.11-0.24)$ & $0.19(0.14-0.26)$ & $0.20(0.14-0.28)$ \\
\hline Quintile 4 & $0.12(0.09-0.17)$ & $0.12(0.08-0.17)$ & $0.16(0.11-0.22)$ & $0.15(0.10-0.21)$ \\
\hline Higher poverty & $0.07(0.05-0.10)$ & $0.07(0.05-0.11)$ & $0.09(0.06-0.13)$ & $0.08(0.05-0.12)$ \\
\hline \multicolumn{5}{|l|}{ HDI } \\
\hline Less development & 1.00 & 1.00 & 1.00 & 1.00 \\
\hline Quintile 2 & $1.91(1.35-2.63)$ & $1.51(1.03-2.14)$ & $1.98(1.46-2.63)$ & $1.73(1.25-2.34)$ \\
\hline Quintile 3 & $3.40(2.37-4.73)$ & $2.28(1.54-3.27)$ & $2.31(1.68-3.11)$ & $2.00(1.41-2.74)$ \\
\hline Quintile 4 & $4.36(2.99-6.16)$ & $3.27(2.15-4.77)$ & $3.46(2.47-4.72)$ & $2.78(1.93-3.87)$ \\
\hline More development & $14.50(10.00-20.60)$ & $13.70(9.04-20.00)$ & $10.50(7.48-14.30)$ & $8.97(6.23-12.50)$ \\
\hline \multicolumn{5}{|c|}{ Municipal economic importance } \\
\hline Major importance & 1.00 & 1.00 & 1.00 & 1.00 \\
\hline 2 & $0.14(0.09-0.19)$ & $0.16(0.12-0.21)$ & $0.16(0.11-0.21)$ & $0.19(0.15-0.25)$ \\
\hline 3 & $0.08(0.05-0.11)$ & $0.07(0.05-0.09)$ & $0.08(0.06-0.11)$ & $0.09(0.07-0.12)$ \\
\hline 4 & $0.03(0.02-0.04)$ & $0.03(0.02-0.05)$ & $0.04(0.03-0.06)$ & $0.05(0.04-0.07)$ \\
\hline Less importance & $0.01(0.00-0.01)$ & $0.01(0.01-0.02)$ & $0.01(0.01-0.02)$ & $0.02(0.02-0.03)$ \\
\hline \multicolumn{5}{|l|}{ MPI } \\
\hline Lower poverty & 1.00 & 1.00 & 1.00 & 1.00 \\
\hline Quintile 2 & $0.25(0.19-0.33)$ & $0.23(0.16-0.31)$ & $0.27(0.21-0.35)$ & $0.23(0.17-0.30)$ \\
\hline Quintile 3 & $0.18(0.13-0.24)$ & $0.15(0.10-0.21)$ & $0.21(0.16-0.27)$ & $0.19(0.14-0.25)$ \\
\hline Quintile 4 & $0.11(0.07-0.14)$ & $0.11(0.08-0.16)$ & $0.14(0.10-0.18)$ & $0.13(0.10-0.18)$ \\
\hline Higher poverty & $0.04(0.03-0.06)$ & $0.06(0.03-0.08)$ & $0.06(0.04-0.09)$ & $0.07(0.04-0.09)$ \\
\hline
\end{tabular}

95\% Cl: 95\% credible interval; HDI: human development index; MPI: multidimensional poverty index; UBN: unmet basic needs.

\section{Discussion}

This paper applies a combination of spatial analysis techniques and GIS tools to obtain evidence about the effect of the municipal socioeconomic conditions and the risk of mortality due to type 2 diabetes mellitus. These results can contribute to the formation of targeted interventions to reduce the high risk in residential areas.

In summary, the results show a decreased mortality risk due to type 2 diabetes mellitus between 2003 and 2016 in Colombia, both nationally and regionally. In addition, there was a clear positive association between mortality due to type 2 diabetes mellitus and the level of municipal development; the wealthiest and most developed municipalities had higher mortality risks.

The ecological association between the highest risk of diabetes and the richest and most developed municipalities could be explained by several factors. First, these areas are often urbanized and are linked, to a greater extent, to nutritional and food transition processes. The literature has documented how obesity, physical inactivity and metabolic syndrome contribute to the early onset of type 2 diabetes mellitus 34 . The 2012 nutritional status data of adults in Colombia shows that those in urban areas experience an increasing tendency for being overweight, with a risk that is three times higher in relation to that in rural areas, and according to this study, the risk increases with age 35 . 
The nutritional transition involves nutritional and dietary changes that have occurred during changes of economic, demographic, social and health nature 36. Popkin et al. 37 has shown that this issue has been exacerbated by globalization and urbanization. Studies have shown that this transition is increasing and is dramatically occurring in developing countries that have experienced accelerated economic growth in recent years 37 .

Urbanization and economic growth has been characterized by increased access to a modern food distribution market, marked by greater availability of shopping centers, supermarkets, cafes, fast food restaurants, ice cream, and processed foods and beverages with a high fat and caloric load as well as promotion of consumption at higher levels 15 . Likewise, these processes bring technological and transport innovations that contribute to the increase in energy consumption and consequently to the increase of sedentary lifestyles and behaviors 38 . Multilevel studies have also shown the effect on the prevalence of chronic diseases associated with food due to contextual factors, such as the presence and high number of paved roads, a higher percentage of households with televisions, cars and cell phones, and the presence of movie theaters and shopping centers in the community 13,14,39,40.

One important finding of our study was that the poorest regions, such as Orinoquía and Amazonia, show an increase in mortality due to type 2 diabetes mellitus. This was an unexpected finding, given the abovementioned association between type 2 diabetes mellitus and higher wealth. The data from the 2015 National Survey of Demography and Health ${ }^{34}$ partially explain this situation as this region has the highest proportion of the native population in the country. As previously mentioned, ethnicity is a risk factor for developing diabetes. This is also the region with the least coverage of water for consumption and has the least access to education, the highest school dropout rates, the least affiliation to the health social security system, the greatest frequency of health problems, the least access to medical services and the greatest migration to urban areas. These factors all contribute to the modification of the food pattern and environment, negatively affecting the nutritional status of the population, which signifies nutritional transition $35,41,42$.

In accordance with the above, the results of the Morán index and the LISA method show a change between the two periods analyzed, both for men and women.

The high-high risk level passed of being located mainly in the municipalities belonging to the Central, Eastern and Atlantic regions to the Orinoquía and Amazon, Eastern and Atlantic regions. According to the 2015 National Demographic and Health Survey, the Eastern region was in the highest wealth quintile, a factor that according to our findings increases the risk of type 2 diabetes mortality. However, the Atlantic and Orinoquía and Amazon regions are in the quintiles of greater poverty, so it is possible that the poorest regions become soon the most affected due to nutritional transition 34 .

Regarding the decrease in mortality due to type 2 diabetes mellitus, it is important to highlight the difficulties associated with registering this in death certificates. As stated in the introduction, advanced and chronic type 2 diabetes mellitus brings complications such as renal and coronary pathologies that are usually the ultimate cause of death. In this sense, these pathologies could eventually be recorded as primary cause of death. A cross-sectional study conducted in 2016 showed that approximately $20 \%$ of new hypertension (HBP) cases corresponded to diabetes patients, and $6 \%$ of individuals identified as being at risk for developing chronic kidney disease (CKD) had diabetes, and 11\% had hypertension and diabetes $41,42,43$.

A main issue necessary to address is that of data quality. In that sense, research on registration of causes of deaths in Colombia shows that this process has improved considerably in the last 30 years and tends to improve 43,44 . According to Cendales \& Pardo 43 , it is possible that the classification of Colombia rises to the category of country with high quality in the certification of mortality since our percentage of deaths certified as signs, symptoms and ill-defined conditions is less than 10\%. Likewise, the latest World Health Organization (WHO) coverage report of death shows that Colombia's coverage rose from $79.9 \%$ in the period 1990-1994 to $88.1 \%$ in 1995-1999, 93.1\% in the period 2000-2004, and 98.5\% in 2009.

However, some authors such as Urdinola et al. 45 have drawn attention to possible problems related to the quality of mortality data in smaller municipalities of developing countries including Colombia. In our study, the initial review of data at the municipal level found that $13 \%$ of municipalities consistently reported zero cases of type 2 diabetes mortality during the study period. As it was not possible for us to know if this situation was due to a sub-registration of cases, or an inadequate codification of the basic cause of death, we assumed that all zero counts represented a true absence of cases in the year analyzed. 
However, in order to try of getting the maximum possible accuracy we use two different data analysis strategies: first, the Bayesian model, which averages the data of neighboring municipalities decreasing conservatively the possible quality/under-registration problems of some municipalities; second, we carried out the analysis for two periods by grouping several years.

Although efforts were made to improve data analysis, we recognize that limitations still persist. For example, given the probability of underreported deaths among the poorest municipalities, the relative risk (RR) may be overestimated even applying strategies above mentioned. So, RR and their corresponding confidence intervals should be interpreted with caution.

\section{Conclusion}

In recent years in Colombia, the mortality rate due to type 2 diabetes mellitus has decreased in most regions, except for the Orinoquía and Amazonia regions. There is a higher prevalence of diabetes mortality in municipalities with the highest levels of development. In all municipalities, women showed higher mortality rates than men.

\section{Contributors}

K. V. Montoya-Betancur, B. Caicedo-Velásquez and L. S. Álvarez-Castaño participated in all phases of the elaboration of the article.

\section{Additional informations}

ORCID: Karen Valeria Montoya-Betancur (00000002-9561-152X); Beatriz Caicedo-Velásquez (0000-0001-6284-512X); Luz Stella Álvarez-Castaño (0000-0002-8049-5685).

\section{References}

1. American Diabetes Association. Standards of medical care in diabetes - 2018. Diabetes Care 2018; 41 Suppl 1:S1-2.

2. International Diabetes Federation. Diabetes atlas de la FID. 8th Ed. Brussels: International Diabetes Federation; 2017.

3. Aschner P. Epidemiología de la diabetes en Colombia. Avances en Diabetología 2010; 26:95-100.

4. Orozco D, Sánchez E, Garrido A, Quesada J, Carratalá C, Gil V. Trends in mortality from diabetes mellitus in Spain: 1998-2013. Rev Esp Cardiol (Engl Ed) 2017; 70:433-43.

5. Agudelo Botero M, Dávila Cervantes CA. Carga de la mortalidad por diabetes mellitus en América Latina 2000-2011: los casos de Argentina, Chile, Colombia y México. Gac Sanit 2015; 29:172-7.

6. Marro MJ, Cardoso AM, Leite IC. Desigualdades regionales en la mortalidad por diabetes mellitus y en el acceso a la salud en Argentina. Cad Saúde Pública 2017; 33:e00113016.

7. Hill JO, Galloway JM, Goley A, Marrero DG, Minners R, Montgomery B, et al. Scientific statement: socioecological determinants of prediabetes and type 2 diabetes. Diabetes Care 2013; 36:2430-9.

8. World Health Organization. Equity, social determinants and public health programmes. Geneva: World Health Organization; 2010.

9. Aschner P. Diabetes trends in Latin America. Diabetes Metab Res Rev 2002; 18 Suppl 3:S2731.

10. Villalonga-Olives E, Marí-Dell'Olmo M, Gotsens M, Ramos M, Ramon J, Cabeza E, et al. Análisis de desigualdades en mortalidad en áreas pequeñas: queda camino por recorrer. Gac Sanit 2013; 27:378-80. 
11. Connolly V. Diabetes prevalence and socioeconomic status: a population based study showing increased prevalence of type 2 diabetes mellitus in deprived areas. J Epidemiol Community Health 2000; 54:173-7.

12. Barker DJ, Gardner MJ, Power C. Incidence of diabetes amongst people aged 18-50 years in nine British towns: a collaborative study. Diabetologia 1982; 22:421-5.

13. Abu Sayeed M, Ali L, Hussain MZ, Rumi MA, Banu A, Azad Khan AK. Effect of socioeconomic risk factors on the difference in prevalence of diabetes between rural and urban populations in Bangladesh. Diabetes Care 1997; 20:551-5.

14. Attard SM, Herring AH, Mayer-Davis EJ, Popkin BM, Meigs JB, Gordon-Larsen P. Multilevel examination of diabetes in modernising China: what elements of urbanisation are most associated with diabetes? Diabetologia 2012; 55:3182-92.

15. Hill JO, Galloway JM, Goley A, Marrero DG, Minners R, Montgomery B, et al. Scientific statement: socioecological determinants of prediabetes and type 2 diabetes. Diabetes Care 2013; 36:2430-9.

16. González JC, Walker JH, Einarson TR. Costof-illness study of type 2 diabetes mellitus in Colombia. Rev Panam Salud Pública 2009; 26:55-63.

17. Salama I, Sánchez G. Factores de riesgo y complicaciones crónicas en el diagnóstico reciente de la diabetes tipo 2. Rev Cuba Endocrinol 2001; 12:76-81.

18. Whiting D, Guariguata L, Weil C, Shaw J. IDF diabetes atlas: global estimates of the prevalence of diabetes for 2011 and 2030. Diabetes Res Clin Pract 2011; 94:311-21.

19. Young TK, Szathmary EJE, Evers S, Wheatley B. Geographical distribution of diabetes among the native population of Canada: a national survey. Soc Sci Med 1990; 31:129-39.

20. Departamento Administrativo Nacional de Estadística. Necesidades básicas insatisfechas (NBI). https://www.dane.gov.co/index.php/ estadisticas-por-tema/pobreza-y-condicio nes-de-vida/necesidades-basicas-insatisfe chas-nbi (accessed on 01/Apr/2018).

21. Departamento Administrativo Nacional de Estadística. Indicador de importancia económica municipal. https://www.dane.gov.co/ index.php/estadisticas-por-tema/cuentasnacionales/cuentas-nacionales-departamen tales/indicador-de-importancia-economicamunicipal\#informacion-historica-indicadorde-importancia-economica-municipal (accessed on 02/Apr/2018).

22. Departamento Administrativo Nacional de Estadística. Pobreza monetaria y multidimensional en Colombia. https://www.dane.gov.co/ index.php/estadisticas-por-tema/pobreza-ycondiciones-de-vida/pobreza-y-desigualdad/ pobreza-monetaria-y-multidimensional-encolombia-2016\#pobreza-monetaria-por-de partamentos-2016 (accessed on 01/Apr/2018).
23. Departamento Administrativo Nacional de Estadística. Metodología para calucular el indicador de importancia económica municipal: cuentas departamentales. Bogotá: Departamento Administrativo Nacional de Estadística; 2016.

24. Departamento Administrativo Nacional de Estadística. Pobreza monetaria en Colombia. Bogotá: Departamento Administrativo Nacional de Estadística; 2019. (Boletín Técnico, 2018).

25. Barceló MA, Saez M, Cano G, Martínez MA, Martínez JM, Borrell C, et al. Metodos para la suavización de indicadores de mortalidad: aplicación al análisis de desigualdades en mortalidad en ciudades del Estado español (Proyecto MEDEA). Gac Sanit 2008; 22:596-608.

26. Besag J, York J, Mollié A. Bayesian image restoration, with two applications in spatial statistics. Ann Inst Stat Math 1991; 43:1-20.

27. Gelman A. Prior distributions for variance parameters in hierarchical models. Bayesian Anal 2006; 1:515-33

28. Gómez D, Prieto E, Mellado A, Moreno A. Análisis espacial de la mortalidad por enfermedades cardiovasculares en la ciudad de Madrid, España. Rev Esp Salud Pública 2015; 89:27-37.

29. Rue H, Martino S, Chopin N. INLA: functions which allow to perform a full Bayesian analysis of structured additive models using Integrated Nested Laplace Approximation. R Packag version 00. http://www. R-INLA.org (accessed on Apr/2018).

30. Anselin L. Local Indicators of Spatial Association - LISA. Geogr Anal 1995; 27:94-115.

31. Hernández A, Díaz D, Espinoza D, Vilcarromero S. Análisis espacial de la mortalidad distrital por enfermedades cardiovasculares en las provincias de Lima y Callao. Rev Peru Med Esp Salud Pública 2016; 33:185-6.

32. Sridharan S, Tunstall H, Lawder R, Mitchell R. An exploratory spatial data analysis approach to understanding the relationship between deprivation and mortality in Scotland. Soc Sci Med 2007; 65:1942-52.

33. Pfeiffer D, Robinson T, Stevenson M, Stevens K, Rogers D, Clements A. Spatial analysis in epidemiology. Oxford: Oxford University Press; 2008.

34. Profamilia; Ministerio de Salud y Protección Social. Encuesta Nacional de Demografía y Salud Tomo I. Componetnte demográfico. Bogotá: Ministerio de Salud y Protección Social; 2015.

35. Neufeld L, Gutiérrez M, Rubio M. Nutrición en Colombia II: actualización del estado nutricional con implicaciones de política. Bogotá: Banco Interamericano de Desarrollo; 2012.

36. Cruz-Sánchez E. La transición nutricional. Abordaje desde de las políticas públicas en América Latina. Opción: Revista de Ciencias Humanas y Sociales 2016; 32:379-402.

37. Popkin BM, Adair LS, Ng SW. Global nutrition transition and the pandemic of obesity in developing countries. Nutr Rev 2012; 70:321. 
38. Oggioni C, Lara J, Wells J, Soroka K, Siervo M. Shifts in population dietary patterns and physical inactivity as determinants of global trends in the prevalence of diabetes: an ecological analysis. Nutr Metab Cardiovasc Dis 2014; 24:1105-11.

39. Lopez-Zetina J, Lee H, Friis R. The link between obesity and the built environment. Evidence from an ecological analysis of obesity and vehicle miles of travel in California. Health Place 2006; 12:656-64.

40. Mendoza Romo MA, Padrón Salas A, Cossío Torres PE, Soria Orozco M. Prevalencia mundial de la diabetes mellitus tipo 2 y su relación con el índice de desarrollo humano. Rev Panam Salud Pública 2017; 41:e103.

41. Mendoza MA, Zavala GG, Padrón Salas A, Ortiz FJ, Ramírez MC, Salas JA. Asociación del índice de desarrollo humano y diabetes mellitus tipo 2 en unidades de medicina familiar del estado San Luis Potosí, México. Atención Familiar 2017; 24:156-9.
42. Fondo Colombiano de Enfermedades de Alto Costo. Situación de la enfermedad renal crónica, la hipertensión arterial y la diabetes mellitus en Colombia 2016. Bogotá: Fondo Colombiano de Enfermedades de Alto Costo; 2017.

43. Cendales R, Pardo C. Quality of death certification in Colombia. Colomb Med 2018; 49:121-7.

44. Colombia Implementation Working Group. Colombia: a strategy to improve the registration and certification of vital events in rural and ethnic communities. Melbourne: Bloomberg Philanthropies Data for Health Initiative; Civil Registration and Vital Statistics Improvement; University of Melbourne; 2018. (CRVS Country Perspectives).

45. Urdinola BP, Torres Áviles F, Velasco JA. The homicide atlas in Colombia: contagion and under-registration for small areas. Cuadernos de Geografía: Revista Colombiana de Geografía 2017; 26:101-18. 


\section{Resumen}

La prevalencia de la diabetes mellitus tipo 2 ha aumentado a nivel global, principalmente en los países de renta media y baja. El estudio tuvo como objetivo evaluar si en Colombia las variaciones geográficas de la mortalidad por diabetes mellitus tipo 2 son aleatorias o estadísticamente significativas, además de medir el efecto de las condiciones socioeconómicas de los municipios sobre esas variaciones. Se realizó un estudio ecológico de las tendencias en las regiones y sub-regiones, considerando dos periodos (2003-2009 y 2010-2016). La población del estudio incluía adultos entre 20 y 79 años de edad, residentes en cada municipio de Colombia, durante el período de 2003-2016. Las tasas de mortalidad suavizadas y estandarizadas se obtuvieron mediante un ajuste de un modelo bayesiano jerárquico, teniendo en cuenta la estructura espacial de los datos. Cuatro variables socioeconómicas relacionadas con la privación y el desarrollo municipal se incluyeron en el modelo para obtener el riesgo relativo $(R R)$ e intervalos de credibilidad de 95\%. La mortalidad por diabetes mellitus tipo 2 disminuyó entre 2003 y 2016 en Colombia, en los niveles tanto nacional, como regional. Asimismo, hubo una asociación positiva entre mortalidad por diabetes mellitus y nivel de desarrollo municipal; los municipios más ricos y más desarrollados presentaron un mayor riesgo de mortalidad.

Diabetes Mellitus Tipo 2; Estado Nutricional; Análisis Espacial; Determinantes Sociales de la Salud; Mortalidad

\section{Resumo}

A prevalência do diabetes mellitus tipo 2 tem aumentado em nivel global, principalmente nos países de renda média e baixa. O estudo teve como objetivo avaliar se na Colômbia, as variações geográficas da mortalidade por diabetes mellitus tipo 2 são aleatórias ou estatisticamente significativas, além de medir o efeito das condições socioeconômicas dos municípios sobre essas variações. Foi realizado um estudo ecológico das tendências nas regiões e sub-regiões, considerando dois periodos (2003-2009 e 2010-2016). A população do estudo incluía adultos entre 20 e 79 anos de idade, residentes em cada município da Colômbia no período de 2003-2016. As taxas de mortalidade suavizadas e padronizadas foram obtidas pelo ajuste de um modelo bayesiano hierárquico, levando em conta a estrutura espacial dos dados. Quatro variáveis socioeconômicas relacionadas à privação e ao desenvolvimento municipal foram incluídas no modelo para obter o risco relativo (RR) e intervalos de credibilidade de $95 \%$. A mortalidade por diabetes mellitus tipo 2 diminuiu entre 2003 e 2016 na Colômbia, nos níveis tanto nacional quanto regional. Além disso, houve uma associação positiva entre mortalidade por diabetes mellitus e nivel de desenvolvimento municipal; os municípios mais ricos e mais desenvolvidos apresentaram o maior risco de mortalidade.

Diabettes Mellitus 2; Estado Nutricional; Análise Espacial; Determinantes Sociais da Sáude; Mortalidade
Submitted on 29/May/2019

Final version resubmitted on 13/Nov/2019 Approved on 25/Nov/2019 